УДК 351.861: 355.58

\author{
A. І. Білоконь, \\ здобувач магістратури кафедри управління охороною здоров' я та публічного \\ адміністрування, Начіональний університет охорони здоров' я Украӥни імені П. А. Шупика \\ ORCID ID: 0000-0001-8331-7465 \\ O. О. Кравченко, \\ к. ю. н., дочент кафедри управління охороною здоров' я та публічного адміністрування \\ Науіональний університет охорони здоров' я України імені П. А. Шупика \\ ORCID ID: 0000-0002-8561-7426
}

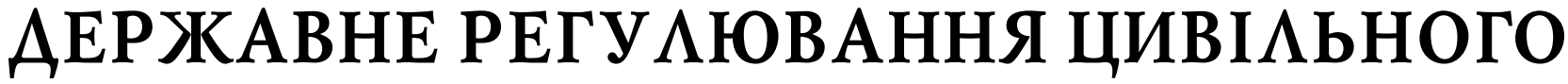 ЗАХИСТУ УКРАЇНИ В СИСТЕМI АЕРЖКАВНОЇ БЕЗПЕКИ УКРАЇНИ
}

\author{
A. Bilokon, \\ Master's student of the Department of Healthcare Management and Public Administration, \\ Shupyk National Healthcare University of Ukraine, Kyiv, Ukraine \\ O. Kravchenko, \\ $\mathrm{PhD}$ in Law, Associate Professor of the Department of Healthcare Management and Public Administration, \\ Shupyk National Healthcare University of Ukraine, Kyiv, Ukraine
}

\section{STATE REGULATION OF CIVIL DEFENSE OF UKRAINE IN THE STATE SECURITY SYSTEM OF UKRAINE}

Питання, пов 'язані з необхідністю державного регулювання цивільного захисту, є досить дискусійними. Державне регулювання є засобом забезпечення рівноваги національної безпеки загалом та сталого розвитку окремих територій. Ужодній країні держава не припинила діяльності щодо розвитку цивільного захисту. Навпаки, пандемія COVID-19 актуалізувала пошук нових напрямів удосконалення взаємовідносин між всіма суб'єктами цивільного захисту і вимагає посилення державного втручання. Мета статті - розглянути сучасний вплив держави на захист населення, територій, навколишнього природного середовища та майна від надзвичайних ситуацій шляхом запобігання таким ситуаціям, ліквідації їх наслідків і надання допомоги постраждалим у мирний час та в особливий період. Інтереси забезпечення безпеки і комплексний підхід до запобігання загроз надзвичайного характерує одним з найбільш актуальних напрямів у діяльності сучасної держави.

У статті досліджено сучасний стан державного регулювання усфері цивільного захисту, зокрема визначено зміни нормативно-правового забезпечення. Як й інші дослідники, зазначаємо необхідність реформування єдиної системи цивільного захисту.

Наведено результати аналізу цілей державного регулювання цивільного захисту. Виокремлено основні стратегічні документи, що спрямовані на реформування державного регулювання у сфері цивільного захисту та становлять основу змін уєдиної системи цивільного захисту та взаємодії суб'єктів цивільного захисту.

Зроблено першу спробу формування методичного підходу для оцінювання ефективності реалізації Стратегії громадської безпеки та цивільного захисту України, що дозволить здійснювати моніторинг стану державного регулювання у сфері цивільного захисту. У статті подано короткий опис основних модулів - оцінка реалізації документів стратегічного планування; оцін- 
ка ступеня досягнення запланованих значень показників документів стратегічного планування відповідно до плану заходів та оцінка ефективності реалізації кожної стратегічної цілі в межах пріоритетів державного регулювання у сфері цивільного захисту, а також достатності ресурсів для такої реалізації, призначених для системної оцінки ефективності досягнення стратегічних цілей та пріоритетів державної політики цивільного захисту.

Issues related to the need for state regulation of civil protection are quite controversial. State regulation is a means of ensuring the balance of national security as a whole and sustainable development of individual territories. In no country has the state stopped activities to develop civil protection. On the contrary, the COVID-19 pandemic has brought to the fore the search for new ways to improve relations between all civil defense actors and calls for increased state intervention. The purpose of the article is to consider the current impact of the state on the protection of the population, territories, environment and property from emergencies by preventing such situations, eliminating their consequences and providing assistance to victims in peacetime and in special periods. The interests of security and an integrated approach to the prevention of threats of an emergency nature is one of the most important areas in the activities of the modern state.

The article examines the current state of state regulation in the field of civil protection, in particular, identifies changes in regulatory and legal support. Like other researchers, the need to reform a unified civil protection system was noted.

The results of the analysis of the goals of state regulation of civil protection are given. The main strategic documents aimed at reforming state regulation in the field of civil protection and form the basis of changes in the unified system of civil protection and interaction of civil defense actors are identified.

The first attempt to form a methodological approach to assess the effectiveness of the Strategy of Public Safety and Civil Protection of Ukraine, which will monitor the state of state regulation in the field of civil protection. The article provides a brief description of the main modules - assessment of the implementation of strategic planning documents; assessment of the degree of achievement of the planned values of indicators of strategic planning documents in accordance with the action plan and assessment of the effectiveness of each strategic goal within the priorities of state regulation in the field of civil protection, as well as adequacy of resources for such implementation. civil protection policy.

Ключові слова: ииВільний захист, національна безпека, державне регулюВання, стратегія, суб'єкти цивільного захисту, єдина система цивільного захисту.

Key words: civil protection, national security, state regulation, strategy, subjects of civil protection, unified system of civil protection.

\section{ПОСТАНОВКА ПРОБАЕМИ}

Протягом останніх кількох десятиліть державна політика, яку сьогодні знаємо як політику цивільного захисту, зазнала значних змін. Після початкових дій, вжитих у рамках цивільної оборони - задуманої для захисту населення у разі військових дій - цивільний захист еволюціонував й посів сьогодні почесне місце у політиці громадської безпеки з метою захисту людей та їх майна перед усіма видами надзвичайних ситуацій та катастроф, чи то внаслідок природних причин, чи дій людей.

Ця визначальна характеристика цивільного захисту як державної політики, яка постійно адаптується до мінливого контексту, вимагає стратегічних інструментів, які б враховували нові загрози та виклики. Наразі до основних проблем відносяться зміна клімату та його наслідки як фрактор, що підвищує інші ризики; національна демографрічна ситуація та її еволюція; зонування та використання земель; та необхідність вирішення ситуацій з особливою вразливістю з соціальних чи осо- бистих причин в умовах надзвичайних ситуацій та катастрофр.

\section{AHА $\Lambda$ ОСТ АНHIX АОС $А$ ОЖЕНЬ

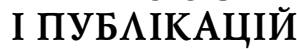

Цивільний захист в Україні та його значення у національній безпеці держави є предметом низки наукових напрацювань. Так, В.С.Кропивницький, В.В. Коваленко у [1] справедливо зазначають, що організація цивільного захисту безпосередньо пов'язана з національною безпекою і обороною держави, а органи та підрозділи цивільного захисту є суб'єктами забезпечення національної безпеки України. При цьому О.П. Борис визначив неоднозначність суджень щодо впливу надзвичайних ситуацій різного характеру та рівня на національну безпеку [2].

С.Р. Артемєв, О.Д. Малько у [3] визначили, що цивільний захист забезпечує екологічну, економічну, соціальну, військову безпеку та протидіє тероризму, включає велику кількість елементів (підсистем), регулюєть- 
ся більше ніж 200 нормативно-правовими актами та різноманітними органами держуправління в межах відповідних компетенцій, а отже, є складним об'єктом державного регулювання.

Цікавим, на наш погляд, визначення системи державного управління цивільним захистом, яке пропонує С.С. Засунько у [4] - це сукупність взаємообумовлених, взаємодіючих органів державного управління та вищих посадових осіб держави, яка в межах чинного законодавства та із залученням наявного у ії розпорядженні потенціалу держави (матеріального, фрінансового, інтелектуального та духовного) здійснює розробку й реалізацію владних, регулюючих, координуючих, контролюючих та нормативних державно-управлінських впливів (рішень) на об'єкти безпеки з метою прогнозування, своєчасного виявлення, запобігання та нейтралізації загроз сталому розвитку вищезазначених об'єктів, передусім життєво важливим національним інтересам. Державне управління може здійснюватися у двох режимах - нормальному та надзвичайному.

М.В. Андрієнко, А.В. Борисов, О.О. Черкасов відзначили, що остання реорганізація МНС України в ДСНС України (кінець 2012 - початок 2013 рр.) ознаменувалась пониженням іï статусу в системі ЦОВВ 3 міністерства до служби, а також зниженням безпосередньої ролі ДСНС України в питаннях щодо забезпечення формування державної політики у сфері ЦЗ, адже відповідні повноваження були покладені на Міністерство оборони України. Безперечно, що нескінченні трансформаційні процеси, в режимі яких постійно перебуває головний суб'єкт державного управління галузевої компетенції у сфері ЦЗ, які відбуваються без належного наукового та практичного обгрунтування, уже самі по собі є вагомим дестабілізуючим чинником функціонування ДСНС України та, як наслідок, усієї ЄДС ЦЗ України загалом [5].

У наукових дослідженнях [6; 7] з питань цивільного захисту вказуються такі проблеми, як недосконалість нормативно- правового забезпечення діяльності у сорері цивільного захисту, необхідність врегулювання ситуації природного, техногенного спрямування та терористичних проявів із боку так званих "ДНР" і "ЛНР" на Сході України, низький рівень матеріально-технічного оснащення підрозділів реагування на НС та не відповідність сучасним вимогам.

Актуальні заходи вдосконалення державного регулювання сорери цивільного захисту виокремив Борис О.П. у [8].

О. Бойко у [9] обгрунтувала потребу удосконалення системи державного управління у соері цивільного захисту в контексті реалізації ухвалених Програми діяльності Кабінету Міністрів України та Цілей сталого розвитку України на період до 2030 року.

Проведений аналіз законодавчих актів у сорері цивільного захисту в Україні показав, що основна їх частина має комплексний характер правового регулювання, охоплює різні аспекти діяльності держави щодо забезпечення безпеки при надзвичайних ситуаціях, особливо, економічні, технічні, організаційні. Проте, враховуючи зміни, що відбулися протягом 2020-2021 років, потребують перегляду характеристик державного регулювання у сорері цивільного захисту в Україні.

\section{META CTATTI}

Мета статті - розглянути сучасний вплив держави на захист населення, територій, навколишнього природного середовища та майна від надзвичайних ситуацій шляхом запобігання таким ситуаціям, ліквідації їх наслідків і надання допомоги постраждалим у мирний час та в особливий період.

\section{ВИК ААА ОСНОВНОГО МАТЕРІААУ АОС IIАХЕНHЯ}

Функції держави реалізуються через державний механізм, невід'ємною частиною якого в більшості держав у сучасних умовах $є$ системи забезпечення безпеки, в тому числі в сорері захисту населення і територій від надзвичайних ситуацій. Розвиток суспільних відносин у різних сфрерах життєдіяльності суспільства і держави, ускладнення політичних, соціальних і економічних процесів, характеризуються різними протиріччями, пов'язаними з переслідуванням державами певних інтересів у тій чи іншій сорері. Переслідувані інтереси багато в чому обумовлені намірами однієї держави або групи держав займати домінуюче становище в сферах геополітики та економіки, що мають стратегічне значення. Водночас для зазначених явищ слід вважати характерним високий ступінь схильності до загроз різного виду і властивостей, оскільки процеси, спрямовані на реалізацію заходів щодо досягнення тих чи інших державних інтересів, виникають, як правило, у взаємодії з навколишнім середовищем, що включає в себе як сприятливі, так і несприятливі умови. Ця обставина багато в чому визначає прояв підвищеного інтересу держави до стану захищеності від різного роду загроз, що мають різні джерела походження, і здатних вплинути на всі сорери життєдіяльності.

Міжнародна ситуація, а також ситуація нестабільності в окремих галузях національної економіки, що склалася в Україні наразі, показують, що не менш важливими, крім загроз військового характеру, тероризму та економічних криз, є загрози, що проявляються у формі подій надзвичайного характеру, і викликані природними або техногенними фракторами. Отже, інтереси забезпечення безпеки і комплексний підхід до запобігання загроз надзвичайного характеру є одним з найбільш актуальних напрямків у діяльності сучасної держави, і вимагають однакового підходу в державному регулюванні питань безпеки. Тому основними цілями державного регулювання цивільного захисту є:

підвищення ролі і значення цивільного захисту в забезпеченні національної безпеки країни;

створення системи безпеки країни від загроз і небезпек;

забезпечення безпеки життєдіяльності населення;

гуманізація суспільних відносин на основі соціальної спрямованості проведених заходів.

Правове забезпечення державного регулювання у сорері цивільного захисту фрормується з доволі великої кількості нормативно-правових актів, зокрема Кодексу цивільного захисту України [10]; Законів України; постанов Кабінету Міністрів України та нормативних документів центральних органів виконавчої влади. Безпосередньо здійснення заходів цивільного захисту в державі, склад органів управління та сил цивільного захис- 
ту, планування діяльності, порядок виконання завдань та організації взаємодії визначено Положенням про єдину державну систему цивільного захисту [11], згідно з яким встановлено режими функціонування (повсякденного, підвищеної готовності, надзвичайної ситуації та надзвичайного стану) на різних рівнях управління (державному, регіональному, місцевому, об'єктовому).

В Україні, об'єкти підвищеної небезпеки, якіє реальною загрозою для виникнення надзвичайної ситуації техногенного та природного характеру, розміщуються нерівномірно (табл. 1), зокрема у 2020 р. найбільше їх розміщено на території Одеської, Дніпропетровської та Вінницької обл., проте найнебезпечніші - у Вінницькій, Одеській та Івано-Франківській обл., переважно це газопроводи, АЗК/АЗС. В Україні об'єкти підвищеної небезпеки ідентифікуються та обліковуються у Державному реєстрі об'єктів підвищеної небезпеки військового призначення (веде Міноборони); відомостях Держпраці, інформуються Державна служба з надзвичайних ситуацій, Держекоінспекції, державної санітарно-епідеміологічної служби, Держархбудінспекції, а також відповідній місцевій держадміністрації або виконавчому органу місцевої ради.

Цивільний захист в Україні за останні десятиліття зазнав значного реформування, не без труднощів у координації між всіма суб'єктами державного управління. За цей час були створені нові державні інституції та ресурси, серед яких важлива роль належить саме суб'єктам забезпечення цивільного захисту з урахуванням особливостей, визначених Законом України "Про національну безпеку України" [13] (сили цивільного захисту віднесено п. 16 ст. 1 віднесено до сектору безпеки і оборони) та повноваження яких у сфері цивільного захисту встановлено Кодексом цивільного захисту України. А реорганізація сил цивільного захисту передбачена Стратегією рефрормування системи Державної служби України з надзвичайних ситуацій [14].

Так само кількість державних правоохоронних органів (які здійснюють правовстановлюючу, правозабезпечувальну, правопримушувальну і правовідновлювальну діяльність) збільшилася та вони зміцнили свої можливості та ресурси на місцях, щоб держава могла краще реагувати на надзвичайні ситуації та події. Також внаслідок адміністративної реформи в Україні об'єднані територіальні громади та місцеві органи самоврядування забезпечені більшими й кращими ресурсами в межах їх юрисдикції, тим самим підвищуючи спроможність своєчасно реагувати на надзвичайні ситуації. На зміст державного регулювання цивільного захисту впливає й курс на євроінтеграцію, обраний Україною, зокрема у червні 2021 р. $з$ метою реалізації Стратегії національної безпеки України, затвердженої Указом Президента України від 14 вересня 2020 року № 392 [15], виконання зобов'язань, узятих Україною згідно з Угодою про асоціацію між Україною, з однієї сторони, та Європейським Союзом, Європейським співтовариством з атомної енергії і їхніми державами-членами, з іншої сторони, було розроблено проєкт Стратегії громадської безпеки та цивільного захисту України [16], в якому пропонується визначити пріоритети національних інтересів у сорері громадської безпеки та цивільного захисту, зокрема:
Таблиця 1. Наявність підвищеної небезпеки в Україні у 2020 р.

\begin{tabular}{|c|c|c|}
\hline Область & $\begin{array}{c}\text { Кількість } \\
\text { об'єктів } \\
\text { підвищеної } \\
\text { небезпеки }\end{array}$ & $\begin{array}{c}\text { Наявність } \\
\text { об'єктів } \\
\text { підвищеної } \\
\text { небезпеки } \\
1 \text { класу }\end{array}$ \\
\hline АР Крим & немає даних & немає даних \\
\hline Вінницька & 77 & 8 \\
\hline Волинська & 46 & - \\
\hline Дніпропетровська & 94 & 1 \\
\hline $\begin{array}{l}\text { Криворізький район } \\
\text { Дніпропетровської обл. }\end{array}$ & 36 & 3 \\
\hline Донецька & 25 & 1 \\
\hline Житомирська & 54 & 1 \\
\hline Закарпатська & 44 & 3 \\
\hline Запорізька & 25 & 1 \\
\hline Івано-Франківська & 56 & 6 \\
\hline Київська & 41 & 4 \\
\hline Кіровоградська & 46 & 1 \\
\hline Луганська & 10 & - \\
\hline Львівська & 57 & 5 \\
\hline Миколаївська & 53 & 2 \\
\hline Одеська & 104 & 12 \\
\hline Полтавська & 40 & 4 \\
\hline Рівненська & 7 & 1 \\
\hline Сумська & 23 & - \\
\hline Тернопільська & 20 & 5 \\
\hline Харківська & 19 & - \\
\hline Херсонська & 13 & 2 \\
\hline Хмельницька & 24 & - \\
\hline Черкаська & 12 & 1 \\
\hline Чернівецька & 55 & 1 \\
\hline Чернігівська & 6 & - \\
\hline
\end{tabular}

Джерело: узагальнено авторами за [12].

утвердження конституційного імперативу щодо розгляду людини, її життя і здоров'я, честі і гідності, недоторканності і безпеки як найвищої соціальної цінності в Україні;

розбудова України як безпечної держави, де визнається і діє принцип верховенства права, держава захищає громадян і суспільство;

послідовна реалізація системних підходів у сорері громадської безпеки та цивільного захисту;

інтеграція України в європейський та євроатлантичний безпековий простір;

виокремлено криміногенні загрози, фактори гібридної війни, кіберзагрози, фактор пандемій та біологічних загроз, загрози техногенного характеру, соціальні та інші загрози, недоліки правового регулювання.

Вищезазначена Стратегія враховує положення Стратегії воєнної безпеки України "ВОЄННА БЕЗПЕКА ВСЕОХОПЛЮЮЧА ОБОРОНА" [17], де також відзначені загрози виникнення надзвичайних ситуацій, зокрема спричинених епідеміями та у разі повномасштабної війни.

Відповідно до Концепції управління ризиками виникнення надзвичайних ситуацій техногенного та природного характеру [18] основними механізмами державного регулювання у сорері управління ризиками $є$ державна стандартизація, сертифікація, державна експертиза, державний нагляд і контроль, ліцензування, економічне регулювання, декларування безпеки небезпечних об'єктів і страхування. При цьому вплив державного регулювання повинен визначатися з урахуванням значень реальних ризиків конкретних об'єктів управління, 
а також здійснених заходів щодо мінімізації ризиків на всіх стадіях життєвого циклу небезпечних об'єктів. У вищезазначеній концепції базисом державного регулювання у сфері техногенної та природної безпеки повинні стати економічні механізми, їх метою $є$ утворення економічного фундамента функціонування цієї системи на всіх рівнях управління безпекою.

Рада національної безпеки і оборони України на основі проведеного аналізу стану виконання завдання щодо проведення огляду громадської безпеки та цивільного захисту, у своєму рішенні, введеному в дію Указом Президента України від 29 грудня 2020 року № 597/ 2020 [19], відзначила недостатню ефективність ужитих компетентними органами заходів для досягнення встановлених цілей. Так, дефіцит коштів, застарілі організаційні структури та застаріле, дефектне технічне обладнання призвели до того, що суб'єкти, задіяні у Єдиній державній системі цивільного захисту, часто не можуть реагувати досить швидко, що призводить до великої кількості жертв. Крім того, самі рятувальники піддавалися великому ризику під час рятувальних операцій через відсутність належного захисного обладнання, такого як шоломи, захисне взуття та апарати для дихання.

3 метою підвищення ефективності реалізації Стратегії громадської безпеки та цивільного захисту України та задля моніторингу стану цивільної безпеки пропонуємо такі методичний підхід до оцінювання реалізації іiї стратегічних пріоритетів, що дозволить здійснювати моніторинг досягнення стратегічних цілей. Для системної оцінки ефективності реалізації кожної стратегічної цілі у сорері цивільного захисту складається з декількох взаємопов'язаних модулів:

Модуль 1 - Оцінка реалізації документів стратегічного планування (оцінка відповідності документів стратегічного планування основним пріоритетам державного регулювання у сорері цивільного захисту).

У модулі 1 в якості вихідних використовуються такі дані:

перелік пріоритетів, включених до державних програм суб'єктів цивільного захисту;

перелік стратегічних цілей, встановлених у Стратегії громадської безпеки та цивільного захисту України;

перелік показників стану цивільного захисту.

У першому модулі виконується також оцінка рівня планування заходів у державних програмах суб'єктів цивільного захисту для досягнення показників, встановлених Стратегію національної безпеки України, Стратегії громадської безпеки та цивільного захисту України, Стратегію воєнної безпеки України та відповідними планами заходів щодо їх реалізації. Зокрема, наприклад, у напрямі захисту населення і територій від надзвичайних ситуацій можна застосувати такі показники стану: зниження кількості НС природного і техногенного характеру, кількості пожеж, кількості подій на водних об'єктах, чисельності населення, яка загинула (в НС, при пожежах, в пригодах на водних об'єктах тощо), ступінь забезпечення готовності сил і засобів територіальної підсистеми єдиної системи цивільного захисту до виконання всього спектра завдань, частка муніципальних утворень, в яких створено "Безпечне місто", частка населення, яке пройшло підготовку у сорері захисту населення і територій від надзвичайних ситуацій.
Модуль 2 - Оцінка ступеня досягнення запланованих значень показників документів стратегічного планування відповідно до плану заходів. Призначений для оцінки ступеня досягнення планових значень показників документів стратегічного планування у сфері цивільного захисту й оцінки ефективності реалізації кожного пріоритету державного регулювання.

Вихідними даними для обчислення узагальнених показників, що характеризують реалізацію кожного пріоритету, $є$ :

відповідні плани заходів з реалізації вищезазначених стратегій;

бюджетні програми, наприклад "Забезпечення діяльності сил цивільного захисту";

концепції /програми суб'єктів цивільного захисту; щорічні державні доповіді про стан цивільного захисту;

форми звітності у сфері цивільного захисту тощо.

Для оцінки реалізації кожної цілі і кожного пріоритету доцільно сорормувати систему показників та на основі досягнутих фрактичних значень показників сфрормувати оцінку комплексного показника за кожною ціллю та пріоритетом та візуалізувати отримані результати у вигляді діаграм, таблиць та інших графрічних ілюстрацій. Все показники попередньо нормуються і приводяться до відносних однорідних показників для можливості подальшого визначення узагальнених індексів, які характеризуватимуть кожний напрям державного регулювання у сорері цивільної безпеки.

Оцінка ефективності реалізації кожної стратегічної цілі і кожного напряму визначається як ступінь (у \%) досягнення цільових значень комплексних показників. Під "ефрективністю" в рамках планування і виконання заходів у сорері цивільного захисту розуміємо ступінь досягнення цільових показників, передбачених документами стратегічного планування у сфері цивільного захисту, за рахунок проведення відповідних заходів.

Кожен комплексний показник, що характеризує виконання напряму/пріоритету Стратегії громадської безпеки та цивільного захисту України обчислюється як середнє арифрметичне з відносних показників, вимірюваних в частках одиниці або \%. Відповідно рівень реалізації того чи іншого напряму державного регулювання вимірюється від 0 до 1 (або від 0 до 100\%).

Модуль 3 - Оцінка ефрективності реалізації кожної стратегічної цілі в межах пріоритетів державного регулювання у сорері цивільного захисту, а також достатності ресурсів для такої реалізації.

Для розрахунків за модулем 3 необхідними $є$ результати розрахунків за модулем 2, фрактичні значення досягнення показників, інтегральних індексів, що характеризують фрактичне виконання напрямів державного регулювання у сорері цивільного захисту. В результаті реалізації модуля 3 оцінюється достатність ресурсів для досягнення стратегічних /оперативних цілей та пріоритетів. У межах цього модулю оцінюється такожй ресурсозабезпеченість напрямів державного регулювання у сорері цивільного захисту. Під "ресурсозабезпеченістю" реалізації кожного напряму держрегулювання розуміємо забезпеченість фрінансовими, технічними, організаційно-кадровими та нормативно-методичними ресурсами. 


\section{ВИСНОВКИ}

На підставі вищевикладеного можна зробити висновок, що державне регулювання цивільного захисту $\epsilon$ інтегрованим з політикою національної безпеки. Ідеальний рівень цивільного захисту грунтується на п'яти передумовах: відповідний правовий аспект цивільного захисту, наявність допоміжної інфрраструктури, складання бюджету, механізми координації між суб'єктами цивільного захисту та мета державної стратегії цивільного захисту.

Запропонований у статті методичний підхід дозволить не лише здійснювати моніторинг фактичного рівня цивільного захисту, порівнювати суб'єктів цивільного захисту за ступенем реалізації Стратегії громадської безпеки та цивільного захисту України, виявляти авангардних і ар'єргардних суб'єктів, а також порівнювати рівень витрачених ресурсів і рівень ефективності реалізації відповідної стратегії кожним суб'єктом України.

Перспективами наукових розвідок $є$ вирішення проблемних питань оцінювання рівня державного регулювання цивільного захисту на різних рівнях: держави, регіону, місцевого самоврядування та об'єднаних територіальних громад.

\section{Література:}

1. Кропивницький В.С., Коваленко В.В. Роль цивільного захисту у забезпеченні національної безпеки України. Науковий вісник: Державне управління. 2018. № 1, DOI: https://doi.org/10.32689/10.32689/26180065-2018-1/1-48-56

2. Борис О.П. Аналіз і узагальнення результатів соціологічного дослідження щодо загроз національної безпеки у сфері цивільного захисту. Інвестиції: практика та досвід. 2019. № 15. С. 102-106. DOI: 10.32702/23066814.2019.15.102

3. Артем'єв С.Р., Малько О.Д. Цивільний захист як чинник системи забезпечення національної безпеки. Наука і правоохорона. 2018. № 2. C. 42-49. URL: http:/ /nbuv.gov.ua/UJRN/Nip_2018_2_7

4. Засунько С.С. Місце та роль державного управління у системі забезпечення цивільного захисту в Україні. Науковий вісник Львівського державного університету внутрішніх справ. Серія юридична. 2011. № 3. URL: https://www.Ivduvs.edu.ua/documents_pdf / visnyky/nvsy/03_2011/11zsszvu.pdf

5. Андрієнко М.В., Борисов А.В., Черкасов О.О. Реалізація державної політики у сфрері цивільного захисту: реорганізація центрального органу виконавчої влади України. Державне управління: удосконалення та розвиток. 2019. № 1. DOI: 10.32702/2307-2156-2019.1.3

6. Любінський А. Сучасний стан та перспективи модернізації системи цивільного захисту України Збірник наукових праць. "ЕФЕКТИВНІСТЬ ДЕРЖАВНОГО УПРАВЛІННЯ". 2015. Вип. 43. С. 104-109. URL: http:// www.Ivivacademy.com/vidavnitstvo_1/edu_43/fail/ 15.pdf

7. Андрієнко М.В., Борис О.П. Реформування державної служби з надзвичайних ситуацій України. Науковий вісник: державне управління. 2020. Вип. № 1 (3). С. 8-19.

8. Борис О.П. Науковий підхід визначення пріоритетних напрямів державного регулювання цивільного захисту на основі експертної оцінки. Інвестиції: практика та досвід. 2019. № 17. C. 44-48. DOI: 10.32702/23066814.2019.17.44

9. Бойко О. Стратегія рефрормування державного управління у сорері цивільного захисту з урахуванням євроінтеграції України. Аспекти публічного управління. 2019. Том 7. № 9-10. DOI: 10.15421/151946

10. Кодекс цивільного захисту України: Закон України від 02.10.2012 № 5403-VI URL: https:// zakon.rada.gov.ua/laws/show/5403-17\#Text

11. Положення про єдину державну систему цивільного захисту: постанова КМУ від 9 січня 2014 р. № 11. URL: https://zakon.rada.gov.ua/laws/show/11-2014$\%$ D0\%BF\#Text

12. Відомості про об єкти підвищеної небезпеки Держпраці. URL: https://dsp.gov.ua/vidomosti-proobyekty-pidvyshchenoi-nebezpeky/

13. Про національну безпеку України: Закон України від 21.06.2018 № 2469-VIII. URL: https://zakon.rada.gov.ua/laws/show/2469-19

14. Стратегія реформування системи Державної служби України з надзвичайних ситуацій: розпорядження КМУ від 25 січня 2017 р. № 61-p. URL: https:// zakon.rada.gov.ua/laws/show/61-2017-\%D1\%80\#Text

15. Стратегія національної безпеки України: Указ Президента України від 14.09. 2020 № 392. https:// zakon.rada.gov.ua/laws/show/392/2020\#Text

16. Стратегія громадської безпеки та цивільного захисту України (проєкт) URL: https://mvs.gov.ua/uk/ ministry/proekti-normativnix-aktiv/strategiya-gromadskoyi-bezpeki-ta-civilnogo-zaxistu-ukrayinizatverdzeno-vid-29062021

17. Стратегія воєнної безпеки України "ВОЄННА БЕЗПЕКА - ВСЕОХОПЛЮЮЧА ОБОРОНА": Указ Президента України від 25.03.2021 №121/2021. URL: https://www.president.gov.ua/documents/121202137661

18. Концепція управління ризиками виникнення надзвичайних ситуацій техногенного та природного характеру: розпорядження КМУ від 22.01.2014 р. № 37-р. URL: https://zakon.rada.gov.ua/laws/show/37-2014$\%$ D1\%80\#Text

19. Рішення Ради національної безпеки і оборони України від 29.12. 2020 "Про результати проведення огляду громадської безпеки та цивільного захист": Указ Президента України від 29.12.2020 № 597/2020. URL: https://www.president.gov.ua/documents/597202036181

References:

1. Kropyvnyts'kyj, V.S. and Kovalenko, V.V. (2018), "The role of civil protection in ensuring the national security of Ukraine", Naukovyj visnyk: Derzhavne upravlinnia, vol. 1. DOI: https://doi.org/10.32689/10.32689/26180065-2018-1/1-48-56

2. Borys, O.P. (2019), "Analysis and generalization of the results of a sociological survey on threats to national security in the field of civil protection", Investytsii: praktyka ta dosvid, vol. 15, pp. 102-106. DOI: 10.32702/ 2306-6814.2019.15.102

3. Artem'iev, S.R. and Mal'ko, O.D. (2018), "Malko Civil protection as a factor in the system of national security", 
Nauka i pravookhorona, vol. 2, pp. 42-49, available at: http://nbuv.gov.ua/UJRN/Nip_2018_2_7 (Accessed 20 Sept 2021).

4. Zasun'ko, S.S. (2011), "The place and role of public administration in the system of civil protection in Ukraine", Naukovyj visnyk L'vivs'koho derzhavnoho universytetu vnutrishnikh sprav. Seriia iurydychna, vol. 3, available at: https://www.Ivduvs.edu.ua/documents_pdf/visnyky/ nvsy/03_2011/11zsszvu.pdf (Accessed 20 Sept 2021).

5. Andriienko, M.V. Borysov, A.V. and Cherkasov, O.O. (2019), "Implementation of state policy in the field of civil protection: reorganization of the central executive body of Ukraine", Derzhavne upravlinnia: udoskonalennia ta rozvytok, vol. 1. DOI: 10.32702/2307-2156-2019.1.3

6. Liubins'kyj, A. (2015), "Current state and prospects of modernization of the civil protection system of Ukraine", Zbirnyk naukovykh prats'. "Efektyvnist' derzhavnoho upravlinnya", vol. 43, pp. 104-109, available at: http://www.Ivivacademy.com/vidavnitstvo_1/ edu_43/fail/15.pdf (Accessed 20 Sept 2021).

$\overline{7}$. Andriienko, M.V. and Borys, O.P. (2020), "Reforming the civil service for emergencies of Ukraine", Naukovyj visnyk: derzhavne upravlinnia, viol. 1 (3), pp. 8-19.

8. Borys, O.P. (2019), "Scientific approach to determining the priority areas of state regulation of civil protection on the basis of expert assessment", Investytsii: praktyka ta dosvid, vol. 17, pp. 44-48. DOI: 10.32702/ 2306-6814.2019.17.44

9. Bojko, O. (2019), "Strategy of public administration reform in the field of civil protection taking into account Ukraine's European integration", Aspekty publichnoho upravlinnia, vol. 7, vol. 9-10. DOI: 10.15421/151946

10. Verkhovna Rada of Ukraine (2012), "Code of Civil Protection of Ukraine", available at: https://zakon.rada.gov.ua/laws/show/5403-17 \#Text (Accessed 10 Sept 2021).

11. Cabinet of Ministers of Ukraine (2014), Resolution "Regulations on the unified state system of civil protection", available at: https://zakon.rada.gov.ua/laws / show /11-2014-\%D0\%BF\#Text (Accessed 10 Sept 2021).

12. State Service of Ukraine for Labor (2021), "Information on objects of the increased danger of the State Labor Service", available at: https://dsp.gov.ua/ vidomosti-pro-obyekty-pidvyshchenoi-nebezpeky/ (Accessed 10 Sept 2021).

13. Verkhovna Rada of Ukraine (2018), The Law of Ukraine "On the national security of Ukraine", available at: https://zakon.rada.gov.ua/laws/show/2469-19 (Accessed 10 Sept 2021).

14. Cabinet of Ministers of Ukraine (2017), Resolution "Strategy for reforming the system of the Civil Service of Ukraine for Emergencies", available at: https:// zakon.rada.gov.ua/laws/show /61-2017-\%D1\%80\#Text (Accessed 10 Sept 2021).

15. President of Ukraine (2020), Decree "National Security Strategy of Ukraine", available at: https:// zakon.rada.gov.ua/laws/show/392/2020\#Text (Accessed 10 Sept 2021).

16. Ministry of Internal Affairs of Ukraine (2021), "Strategy of public safety and civil protection of Ukraine (project)", available at: https://mvs.gov.ua/uk/ ministry/proekti-normativnix-aktiv /strategiyagromadskoyi-bezpeki-ta-civilnogo-zaxistu-ukrayinizatverdzeno-vid-29062021 (Accessed 10 Sept 2021).

17. President of Ukraine (2021), Decree "Military Security Strategy of Ukraine "Military Security Comprehensive Defense"", available at: https:// www.president.gov.ua/documents/1212021-37661 (Accessed 10 Sept 2021).

18. Cabinet of Ministers of Ukraine (2014), Resolution "The concept of risk management of emergencies of manmade and natural nature", available at: https:// zakon.rada.gov.ua/laws/show /37-2014-\%D1\%80\#Text (Accessed 10 Sept 2021).

19. President of Ukraine (2020), Decree "Decision of the National Security and Defense Council of Ukraine dated 29.12. 2020 "On the results of the review of public safety and civil protection", available at: https://www.president.gov.ua/documents/5972020-36181 (Accessed 10 Sept 2021).

Стаття надійшла до редакиї 20.09.2021 p.

\section{Науково-практичний журнал} «ЕКОНОМІКА ТА ДЕРЖАВА»

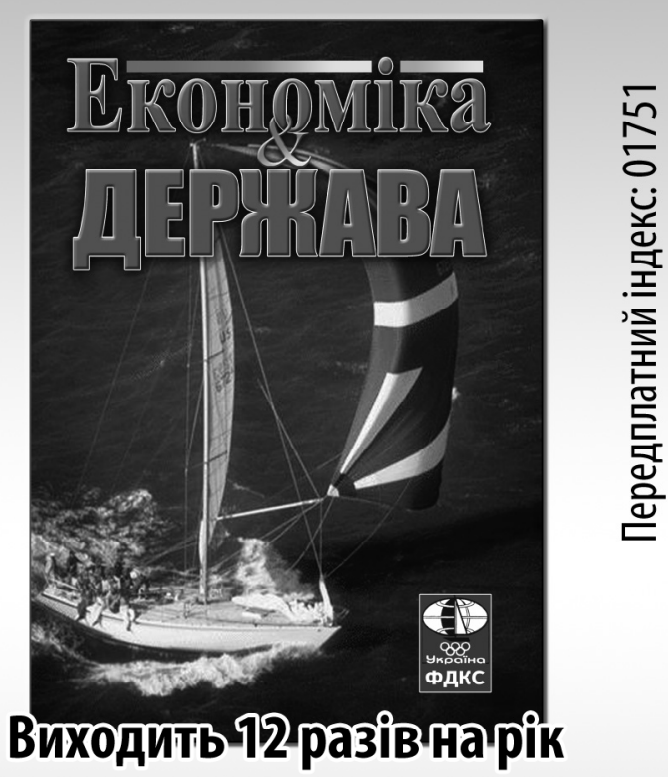

наукове фахове видання України 3 ПИТАНЬ ЕКОНОМІКИ

(Категорія «Б»)

Наказ Міністерства освіти і науки України від 28.12.2019 №1643

Спеціальності - 051, 071, 072, 073, 075, 076, 292.

www. economy.in.ua

e-mail: economy_2008@ukr.net

тел.: (044) 223-26-28

(044) 458-10-73 